\title{
Pengaruh Efisiensi Waktu Tunggu, Biaya Pelayanan, Kebersihan, serta Kenyamanan Ruangan terhadap Kepuasan Pasien (Studi Pada Pelayanan Instalasi Rawat Jalan Rumah Sakit Medika Lestari)
}

\author{
Firdaus Razie Sugondo ${ }^{1}$, Puspita Faustina ${ }^{l}$, Innocentius Bernarto ${ }^{l}$ \\ Universitas Pelita Harapan Tangerang \\ Email: * Firdaus.sugondo@gmail.com, puspita.faustina@yahoo.co.id, \\ innobernarto@gmail.com
}

\begin{abstract}
Seeing the importance of patient adherence in a patient's therapeutic journey and several factors related to patient adherence, we tried to assess patient satisfaction with the outpatient unit of Medika Lestari Hospital in 2021. Therefore, we conducted a cross-sectional study of patients aged 18-59 years to assess their satisfaction with the services of the Medika Lestari Hospital outpatient unit on 28 July 2021. We evaluated 4 main dimensions, namely: (1) Efficiency, (2) Convenience; (3) Cleanliness; and (4) Financing. The survey instrument was prepared based on the consensus of the research team and has good validity and reliability based on the Pearson and Cronbach-alpha tests. All statistical analyzes were performed with SmartPLS software version 3.3.3. A total of 206 patients were recruited, with a composition of $102(49.51 \%)$ males and 104 (50.49\%) females. There were 43 (20.87\%), 103 (50\%), 46 (22.33\%), and 14 $(6.80 \%)$ patients, respectively, in the age categories 18-25 years, 26-35 years, 36-45 years, and 46-59 years, respectively. We found that the average patient satisfaction with outpatient services at Medika Lestari Hospital was 4.23 (84.6\%). The average patient satisfaction score for the outpatient service at the Medika Lestari Hospital is $4.23 \pm 0.363$. In addition, we also found that
\end{abstract}

service efficiency, cost, cleanliness of the service room, and comfort of the service room had a positive effect on patient satisfaction in the outpatient unit at Medika Lestari Hospital.

Keywords: Patient satisfaction, efficiency, service costs, cleanliness, and comfort

\section{PENDAHULUAN}

Rumah sakit adalah institusi yang memegang peran esensial dalam suatu komunitas. Hal ini tercermin dari angka kesakitan akibat kecelakaan, penyakit infeksius, ataupun degeneratif selalu ada setiap hari, dan rumah sakit diperlukan untuk mendiagnosis, mengobati dan mengelola berbagai jenis penyakit tersebut. Meskipun telah terjadi penurunan tajam tingkat admisi rawat inap rumah sakit hingga $75 \%$ dibandingkan sebelum masa pandemi COVID-19, sesuai laporan studi observasional di Qatar ${ }^{1}$, angka perawatan pasien di unit gawat darurat dan rawat jalan telah mengalami peningkatan $66.6 \%$ dibandingkan sebelum pandemi COVID-19. ${ }^{2}$ Selain itu, penurunan angka admisi rawat inap rumah sakit terjadi sebagai bentuk adaptasi untuk meminimalisasi transmisi SARS-CoV-2 antar pasien, tenaga kesehatan, dan tenaga kerja lainnya di rumah sakit. Hampir seluruh rumah sakit telah merestriksi tindakan 
pembedahan elektif. $^{1,3,4}$

Tenaga medis dalam suatu rumah sakit dihadapkan oleh persoalan kepatuhan pasien agar tujuan utama terapi medis dapat tercapai. Adherensi dan kepatuhan pasien merupakan simbol kepercayaan pasien terhadap perawatan medis yang ditawarkan oleh sebuah rumah sakit secara utuh. Dari perspektif penyedia layanan kesehatan, kepatuhan terapeutik adalah masalah klinis utama karena dua alasan. Pertama, ketidakpatuhan dapat berdampak besar pada luaran pengobatan dan konsekuensi klinis jangka panjang. Untuk ketidakpatuhan terapeutik pada penyakit menular, konsekuensinya dapat mencakup tidak hanya dampak langsung seperti kegagalan pengobatan, tetapi juga menimbulkan dampak eksternal berupa perkembangan mikroorganisme resisten. ${ }^{5}$ Kedua, adherensi pasien yang buruk akan menyebabkan peningkatan beban keuangan bagi masyarakat. Suatu studi telah melaporkan bahwa ketidakpatuhan terapeutik berkaitan dengan kunjungan perawatan darurat yang berlebihan, rawat inap dan biaya pengobatan yang lebih tinggi. ${ }^{6,7}$ Diperkirakan bahwa $25 \%$ dari admisi rumah sakit di Australia, dan 33\%-69\% dari total admisi rumah sakit terkait pengobatan di Amerika Serikat adalah karena ketidakpatuhan terhadap rejimen pengobatan. ${ }^{5,7}$

Adherensi pasien terhadap perawatan kesehatan yang telah ditawarkan bergantung oleh berbagai faktor. Sulit untuk menemukan hubungan antara input dan kualitas hasil klinis di sektor kesehatan karena layanan kesehatan menawarkan jasa. Banyak variabel seperti faktor sosio-demografis pasien dan tingkat keparahan penyakit mempengaruhi adherensi pasien terhadap perawatan kesehatan. ${ }^{8}$ Salah satu cara terpenting untuk mendapatkan adherensi pasien adalah dengan meningkatkan kualitas layanan yang diberikan dengan meningkatkan semua proses medis, karena kualitas layanan merupakan penentu utama pilihan penyedia layanan kesehatan. $^{9,10}$

Penelitian menunjukkan bahwa beberapa faktor mempengaruhi pilihan pasien terhadap rumah sakit, seperti biaya, fasilitas yang tersedia, perilaku karyawan ${ }^{8}$, reputasi rumah sakit ${ }^{8,}{ }^{11}$, partisipasi jaringan dan persaingan pasar rumah sakit ${ }^{12}$, fisik rumah sakit $^{13}$, serta lokasi dan aksesibilitas rumah sakit. $^{14,} 15$ Melihat pentingnya adherensi pasien dalam suatu perjalanan terapeutik pasien, dan beberapa faktor yang berhubungan dengan adherensi pasien tersebut, peneliti mencoba melakukan penilaian kepuasan pasien terhadap unit rawat jalan Rumah Sakit Medika Lestari pada tahun 2021.

\section{METODE PENELITIAN}

Penelitian ini adalah studi potong lintang untuk menilai kepuasan pasien pada unit rawat jalan Rumah Sakit Medika Lestari pada bulan Agustus 2021. Peneliti mengevaluasi 4 dimensi utama, yakni: (1) Efisiensi; (2) Kenyamanan; (3) Kebersihan; dan (4) Pembiayaan. Pada aspek efisiensi, perihal yang ditanyakan adalah terkait proses pendaftaran yang singkat (E1), waktu tunggu pelayanan dokter yang cepat (E2), proses pembayaran yang singkat (E3), dan proses tebus obat yang singkat (E4). Pertanyaan terkait kebersihan adalah bahwa Rumah Sakit Medika Lestari memiliki ruang tunggu rawat jalan yang bersih (R1), toilet pelanggan yang bersih (R2), lantai dan tembok gedung yang bersih (R3), dan staff menggunakan seragam yang rapi (R4). Aspek kenyamanan yang dinilai adalah bahwa Rumah Sakit Medika Lestari memiliki kursi ruang tunggu yang nyaman (N1), jumlah kursi ruang tunggu yang memadai (N2), desain ruangan yang nyaman (N3), suhu ruangan yang nyaman (N4), suasana ruang tunggu yang tidak bising (N5), dan volume broadcast / pemanggilan pasien jelas (N6).

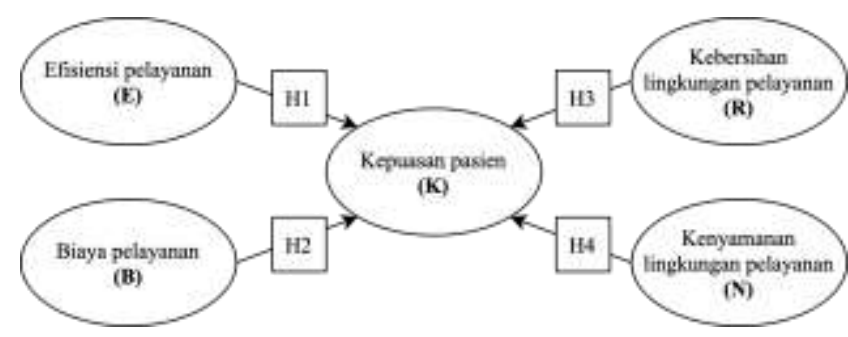

Gambar 1. Model komputasi 
Sampel penelitian ini adalah seluruh pasien rawat jalan Rumah Sakit Medika Lestari pada pukul 11:00, tanggal 21 Agustus 2021 direkrut dalam survei ini. Kriteria inklusi yang peneliti tetapkan dalam survei ini adalah:

1. Berstatus sebagai pasien rawat jalan Rumah Sakit Medika Lestari;

2. Berusia 18-59 tahun; dan

3. Bersedia diikutsertakan dalam survei dengan bukti persetujuan lembar informed consent penelitian.

Pasien dengan gangguan kejiwaan, penglihatan, dan pendengaran dieksklusi dari penelitian. Pengisian kuesioner didampingi oleh salah satu peneliti untuk memastikan sampel memahami maksud pertanyaan dalam kuesioner. Sampel diambil dengan teknik consecutive sampling. Pengisian kuesioner dilakukan oleh pasien di ruang tunggu pasien.

Analisis statistik dilakukan dengan pendekatan Partial Least Square-Structural Equation Modelling (PLS-SEM). Seluruh analisis statistik dilakukan dengan perangkat lunak SmartPLS versi 3.3.3.

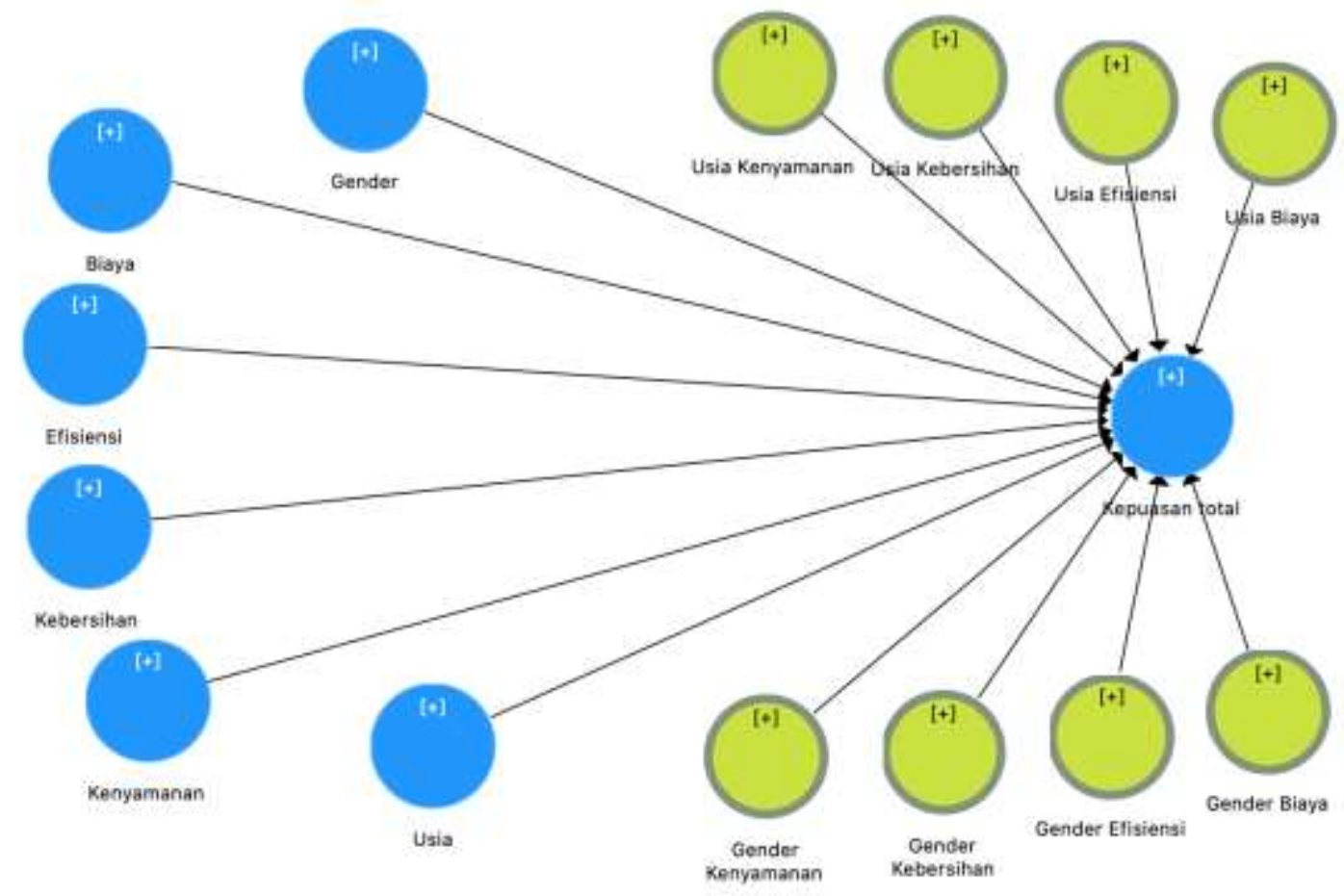

Gambar 2. Pemodelan komputasi masing-masing variabel terhadap kepuasan total pasien.

\section{HASIL DAN PEMBAHASAN}

Sebanyak 206 pasien unit rawat jalan di Rumah Sakit Medika Lestari direkrut dalam penelitian ini, dengan komposisi 102 $(49,51 \%)$ pasien laki-laki dan $104(50,49 \%)$ pasien perempuan. Dari 206 pasien ini, terdapat masing-masing $43(20,87 \%), 103$ (50\%), 46 (22.33\%), dan $14(6.80 \%)$ pasien dengan kategori usia 18-25 tahun, 26-35 tahun, 36-45 tahun, dan 46-59 tahun, secara berturut-turut. Tabel 2 merangkum karakteristik responden dalam penelitian ini.
Peneliti menemukan bahwa rerata kepuasan pasien terhadap pelayanan unit rawat jalan di Rumah Sakit Medika Lestari adalah sebesar 4.23 (84.6\%). Bila ditinjau berdasarkan komponen-komponennya, aspek yang mendapatkan penilaian terendah adalah kebersihan lantai dan tembok Gedung ruang pelayanan rawat jalan dengan rerata skor kepuasan 4.01 \pm 0.902 . Aspek terendah selanjutnya adalah terkait efisiensi waktu tunggu untuk melakukan proses pendaftaran dengan rerata skor $4.06 \pm 0.773$.

Tabel 1. Hasil kepuasan pasien terhadap pelayanan unit rawat jalan Rumah Sakit Medika Lestari 


\begin{tabular}{|c|c|c|c|c|c|c|c|c|}
\hline No & Dimensi & Aspek & $\mathbf{N}$ & Rerata & SB & Median & Min & Maks \\
\hline E1 & Efisiensi & $\begin{array}{l}\text { Proses pendaftaran yang } \\
\text { singkat }\end{array}$ & 206 & 4.06 & 0.671 & 4.00 & 2 & 5 \\
\hline $\mathrm{E} 2$ & & $\begin{array}{l}\text { Waktu tunggu pelayanan } \\
\text { dokter yang cepat }\end{array}$ & 206 & 4.11 & 0.773 & 4.00 & 2 & 5 \\
\hline E3 & & $\begin{array}{l}\text { Proses pembayaran yang } \\
\text { singkat }\end{array}$ & 206 & 4.33 & 0.638 & 4.00 & 2 & 5 \\
\hline \multirow[t]{2}{*}{$\mathrm{E} 4$} & & $\begin{array}{l}\text { Proses tebus obat yang } \\
\text { singkat }\end{array}$ & 206 & 4.15 & 0.851 & 4.00 & 2 & 5 \\
\hline & & Rerata efisiensi & 206 & 4.16 & 0.513 & 4.25 & 2.25 & 5 \\
\hline $\mathrm{R} 1$ & Kebersihan & $\begin{array}{l}\text { Memiliki ruang tunggu } \\
\text { rawat jalan yang bersih }\end{array}$ & 206 & 4.31 & 0.631 & 4.00 & 2 & 5 \\
\hline $\mathrm{R} 2$ & & $\begin{array}{l}\text { Toilet pelanggan yang } \\
\text { bersih }\end{array}$ & 206 & 4.15 & 0.789 & 4.00 & 2 & 5 \\
\hline $\mathrm{R} 3$ & & $\begin{array}{l}\text { Lantai dan tembok gedung } \\
\text { yang bersih }\end{array}$ & 206 & 4.01 & 0.902 & 4.00 & 2 & 5 \\
\hline \multirow[t]{2}{*}{$\mathrm{R} 4$} & & $\begin{array}{l}\text { Staff menggunakan } \\
\text { seragam yang rapi }\end{array}$ & 206 & 4.14 & 0.799 & 4.00 & 2 & 5 \\
\hline & & Rerata kebersihan & 206 & 4.15 & 0.572 & 4.25 & 2.25 & 5 \\
\hline N1 & Kenyamanan & $\begin{array}{l}\text { Kursi ruang tunggu yang } \\
\text { nyaman }\end{array}$ & 206 & 4.22 & 0.645 & 4.00 & 2 & 5 \\
\hline $\mathrm{N} 2$ & & $\begin{array}{l}\text { Jumlah kursi ruang tunggu } \\
\text { yang memadai }\end{array}$ & 206 & 4.30 & 0.580 & 4.00 & 2 & 5 \\
\hline N3 & & $\begin{array}{l}\text { Desain ruangan yang } \\
\text { nyaman }\end{array}$ & 206 & 4.23 & 0.708 & 4.00 & 2 & 5 \\
\hline N4 & & $\begin{array}{l}\text { Suhu ruangan yang } \\
\text { nyaman }\end{array}$ & 206 & 4.33 & 0.592 & 4.00 & 2 & 5 \\
\hline N5 & & $\begin{array}{l}\text { Suasana ruang tunggu yang } \\
\text { tidak bising }\end{array}$ & 206 & 4.35 & 0.620 & 4.00 & 2 & 5 \\
\hline \multirow[t]{2}{*}{ N6 } & & $\begin{array}{l}\text { Volume broadcast/ } \\
\text { pemanggilan pasien jelas }\end{array}$ & 206 & 4.28 & 0.667 & 4.00 & 2 & 5 \\
\hline & & Rerata kenyamanan & 206 & 4.28 & 0.363 & 4.33 & 3.17 & 5 \\
\hline B1 & Biaya & $\begin{array}{l}\text { Biaya dokter yang sesuai } \\
\text { dengan pelayanan }\end{array}$ & 206 & 4.25 & 0.580 & 4.00 & 2 & 5 \\
\hline B2 & & $\begin{array}{l}\text { Biaya pemeriksaan medis } \\
\text { yang terjangkau }\end{array}$ & 206 & 4.27 & 0.671 & 4.00 & 2 & 5 \\
\hline \multirow[t]{2}{*}{ B3 } & & Biaya obat terjangkau & 206 & 4.34 & 0.626 & 4.00 & 1 & 5 \\
\hline & & Rerata biaya & 206 & 4.29 & 0.463 & 4.33 & 1.67 & 5 \\
\hline K & \multicolumn{2}{|c|}{ Kepuasan pasien } & 206 & 4.23 & 0.363 & 4.35 & 3.35 & 5 \\
\hline
\end{tabular}

Keterangan: SB, simpangan baku; Min, minimum; Maks, maksimum

Berdasarkan survei ini, suasana ruang tunggu adalah komponen yang paling tinggi tingkat kepuasannya dengan rerata skor $4.35 \pm 0.620$, disusul oleh biaya obat dengan rerata skor $4.34 \pm 0.626$. Secara umum, dimensi biaya dan kenyamanan pasien memiliki skor yang lebih tinggi dibandingkan efisiensi dan kebersihan. Kebersihan merupakan aspek yang mendapatkan kepuasan paling rendah di antara 3 aspek lainnya. Peneliti mencatat rerata keseluruhan aspek kepuasan pasien rawat jalan di Rumah Sakit Medika Lestari adalah sebesar $4.23 \pm 0.363$.

\section{Evaluasi model pengukuran (measurement model)}

Peneliti melakukan evaluasi model pengukuran (measurement model) dengan uji reliabilitas dan validitas. Uji validitas dimulai dengan pengukuran loading factors dan hasil 
Tabel 2. Evaluasi validitas dan reliabitas pasca delesi data-data invalid pada outer laoding

\begin{tabular}{llll}
\hline & Laten & Outer loading & Keterangan \\
\hline Efisiensi & & & \\
\hline E1 & Proses pendaftaran yang singkat & 0.598 & Invalid \\
\hline E2 & Waktu tunggu pelayanan dokter yang cepat & 0.767 & Valid \\
\hline E4 & Proses pembayaran yang singkat & 0.689 & Invalid \\
\hline Kebersihan & Proses tebus obat yang singkat & 0.726 & Valid \\
\hline R1 & $\begin{array}{l}\text { Memiliki ruang tunggu rawat jalan yang } \\
\text { bersih }\end{array}$ & 0.617 & Invalid \\
\hline R2 & Toilet pelanggan yang bersih & 0.709 & Valid \\
\hline R3 & Lantai dan tembok gedung yang bersih & 0.821 & Valid \\
\hline R4 & Staff menggunakan seragam yang rapi & 0.748 & Valid \\
\hline Kenyamanan & & & \\
\hline N1 & Kursi ruang tunggu yang nyaman & 0.563 & Invalid \\
\hline N2 & Jumlah kursi ruang tunggu yang memadai & 0.548 & Invalid \\
\hline N3 & Design ruangan yang nyaman & 0.623 & Invalid \\
\hline N4 & Suhu ruangan yang nyaman & 0.484 & Invalid \\
\hline N5 & Suasana ruang tunggu yang tidak bising & 0.469 & Invalid \\
\hline N6 & Volume broadcast / pemanggilan pasien jelas & 0.710 & Valid \\
\hline Biaya & & & \\
\hline B1 & Biaya dokter yang sesuai dengan pelayanan & 0.701 & Valid \\
\hline B2 & Biaya pemeriksaan medis yang terjangkau & 0.780 & Valid \\
\hline B3 & Biaya obat terjangkau & 0.727 & Valid \\
\hline Kepuasan & & & Valid \\
\hline K & Kepuasan & 1.000 & \\
\hline
\end{tabular}

Evaluasi outer loading menunjukkan bahwa terdapat setidaknya satu indikator yang invalid pada seluruh laten. Pada laten efisiensi, proses pendaftaran dan pembayaran yang singkat mesti dihapus karena tidak valid. Ruang tunggu rawat jalan dan toilet yang bersih adalah indikator tidak valid yang harus dihapus pada laten kebersihan. Pada laten kenyamanan, terdapat 5 indikator yang tidak valid, yaitu kenyamanan kursi ruang tunggu, desain ruangan, suhu ruangan, suasana ruang tunggu, dan jumlah kursi. Pada laten biaya, hanya biaya obat dan jasa dokter yang invalid. 


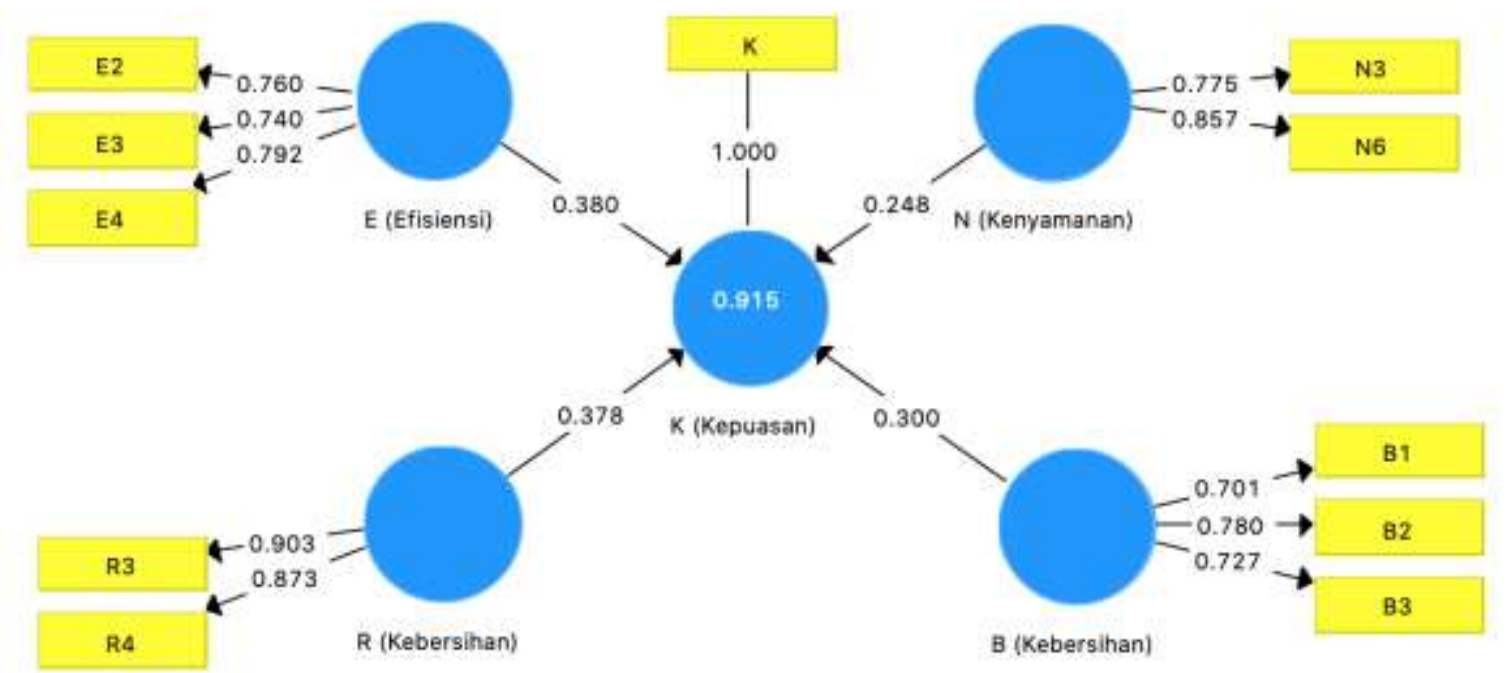

Gambar 3. Evaluasi validitas dan reliabitas awal pasca delesi variabel invalid pada outer loading

Pengujian validitas diskriminan dilakukan dalam 2 tahapan: 1) Kriteria Fornell-Larcker; dan 2) Cross loading. Pada kriteria Forner-Larcker, semua variabel telah memenuhi persyaratan, yang mana hubungan variabel yang sama bernilai lebih besar dibandingkan hubungan antar variabel yang berbeda (Tabel 5).

Tabel 3. Pengujian validitas diskriminan berdasarkan kriteria Fornell-Larcker dan nilai reliabilitas instrumen

\begin{tabular}{|c|c|c|c|c|c|}
\hline & $\begin{array}{c}\text { B } \\
\text { (Biaya) }\end{array}$ & $\begin{array}{c}\mathbf{E} \\
\text { (Efisiensi) }\end{array}$ & $\begin{array}{c}\text { K } \\
\text { (Kepuasan) }\end{array}$ & $\begin{array}{c}\mathrm{N} \\
\text { (Kenyamanan) }\end{array}$ & $\begin{array}{c}\mathbf{R} \\
\text { (Kebersihan) }\end{array}$ \\
\hline \multicolumn{6}{|l|}{ Validitas diskriminan } \\
\hline B (Biaya) & 0.737 & & & & \\
\hline E (Efisiensi) & 0.348 & 0.765 & & & \\
\hline K (Kepuasan) & 0.558 & 0.779 & 1.000 & & \\
\hline N (Kenyamanan) & 0.267 & 0.435 & 0.690 & 0.817 & \\
\hline R (Kebersihan) & 0.155 & 0.494 & 0.741 & 0.518 & 0.888 \\
\hline \multicolumn{6}{|l|}{ Nilai reliabilitas instrumen } \\
\hline Cronbach's Alpha & 0.782 & 0.845 & 1 & 0.781 & 0.701 \\
\hline rho_A & 0.786 & 0.852 & 1 & 0.798 & 0.719 \\
\hline Composite Reliability & 0.781 & 0.79 & 1 & 0.741 & 0.817 \\
\hline $\begin{array}{l}\text { Average Variance Extracted } \\
\text { (AVE) }\end{array}$ & 0.543 & 0.487 & 1 & 0.327 & 0.529 \\
\hline
\end{tabular}

Setelah didapatkan bahwa seluruh variabel memenuhi kriteria Fornell-Larcker, peneliti melakukan pengujian dengan pendekatan cross loading untuk memastikan bahwa tiap indikator telah memenuhi syarat validitas diskriminan. Pada pendekatan ini, nilai hubungan seluruh indikator dengan variabel asalnya lebih tinggi dibandingkan indikator dengan variabel lain. Dengan demikian, seluruh indikator memiliki validitas yang baik dan layak dilanjutkan pada tahan uji reliabilitas.

Penilaian reliabilitas dilakukan dengan melihat nilai Cronbach's Alpha dan composite reliability. Pada seluruh variabel, nilai nilai Cronbach's Alpha dan composite reliability 
telah $\geq 0.7$ (Tabel 5). Hal ini menandakan bahwa instrumen yang peneliti formulasikan memiliki reliabilitas yang baik, dan hasil kuesioner yang diperoleh dapat dipercaya serta layak untuk dilakukan evaluasi model struktural.

\section{Evaluasi model struktual (structural model)}

Evaluasi model struktural dilakukan dengan menilai $R$-square, koefisien jalur, dan T-statistic. Namun, pengujian kolinearitas juga perlu dilakukan sebelum menilai signifikansi pada evaluasi model struktural. Hal ini dilakukan untuk memastikan bahwa tidak terdapat multikolinearitas yang mengganggu pengaruh masing-masing variabel independen (eksogen) terhadap variabel dependen (endogen). Berdasarkan uji kolinearitas, seluruh variabel memiliki nilai $<5$, yang menunjukkan bahwa tidak terdapat adanya multikolinearitas.

Berdasarkan uji $R$-square, didapatkan bahwa 91.5\% variabel endogen (Kepuasan) dipengaruhi oleh variabel eksogen yang ditelaah dalam penelitian ini. Hal ini menandakan bahwa variabel-variabel eksogen berkorelasi kuat dengan variabel endogen. Uji hipotesis dilakukan untuk menegakkan apakah hubungan variabel endogen dan eksogen yang didapatkan bernilai signifikan secara statistik atau tidak. Uji hipotesis dilakukan dengna inner model test yang mencakup koefisien jalur (path coefficient), $\mathrm{t}-$ hitung, dan nilai p. Seluruh variabel eksogen ditemukan memiliki koefisien jalur bernilai positif, yang menandakan adanya hubungan positif antara variabel eksogen dengan endogen.

Selain itu, nilai t-hitung yang didapatkan pada seluruh hipotesis bernilai $>1.96$ dengan nilai $\mathrm{p}<0.05$. Hal ini menandakan bahwa seluruh hipotesis diterima, yakni: H1: efisiensi pelayanan berpengaruh positif terhadap kepuasan pasien; $\mathrm{H} 2$ : biaya pelayanan yang terjangkau berpengaruh positif terhadap kepuasan pasien; H3: bersihnya lingkungan pelayanan berpengaruh positif terhadap kepuasan pasien; dan H4: kenyamanan ruangan pelayanan berpengaruh positif terhadap kepuasan pasien.
Dalam survei ini, peneliti menemukan bahwa tingkat kepuasan pasien unit rawat jalan di Rumah Sakit Medika Lestari ada pada angka 4.23 \pm 0.363 . Kebersihan lingkungan merupakan bagian yang paling mendapatkan skor kepuasan terendah. Lantai dan tembok Gedung adalah komponen kebersihan yang mendapatkan skor paling rendah. Tinjauan sistematis yang disusun oleh Han dkk (2015) menunjukkan bahwa kebersihan permukaan ruangan (tembok, meja, dan lantai) menjadi faktor penting untuk terjadinya hospitalacquired infection (HAI). ${ }^{16}$

Studi di Rumah Sakit Black Lion, Ethiopia melaporkan bahwa kebersihan ruang tunggu dan kamar mandi merupakan faktor determinan kepuasan pasien. ${ }^{17}$ Suatu survei nasional di Thailand menunjukkan bahwa 90\% lebih rumah sakit telah memiliki protokol kebersihan, namun hanya kurang dari setengahnya yang memiliki mekanisme audit penerapakan protokol kebersihan tersebut. ${ }^{18}$ Hal yang sama mungkin terjadi di Rumah Sakit Medika Lestari, yang mana pengawasan implementasi protokol kesehatan belum sepenuhnya terlaksana dengan baik sehingga pasien memiliki kepuasan yang rendah terhadap kebersihan unit rawat jalan Rumah Sakit Medika Lestari.

Efisiensi pelayanan mendapatkan skor yang tidak jauh berbeda dengan skor kebersihan. Waktu tunggu untuk mendapatkan pelayanan dari dokter adalah komponen efisiensi terendah. Efisiensi waktu tunggu pelayanan memang telah menjadi permasalahan di berbagai pusat kesehatan. Survei di Nigeria melaporkan bahwa hampir $50 \%$ pasien merasa kurang puas dengan efisiensi waktu tunggu di Rumah Sakit University of Port Harcourt. ${ }^{19}$ Namun, kepuasan secara umum pasien di rumah sakit tersebut terkait efisiensi lebih dari $75 \%$. Hal ini menandakan bahwa masalah paling besar efisiensi pelayanan terletak pada waktu tunggu yang dibutuhkan oleh pasien untuk bertemu dengan dokter.

Peneliti telah menganalisis pengaruh jenis kelamin terhadap skor kepuasan pelayanan unit rawat jalan Rumah Sakit Medika Lestari. Jenis kelamin tidak 
berhubungan dengan kepuasan pelayanan. Temuan ini sejalan dengan laporan Asamrew dkk (2020), yang mana jenis kelamin bukan merupakan faktor penentu kepuasan umum pelayanan rawat Rumah Sakit Black Lion, Ethiopia. ${ }^{17}$ Studi di Amerika Serikat yang spesifik membahas pengaruh jenis kelamin dengan kepuasan pasien di rumah sakit juga menegaskan bahwa jenis kelamin tidak berhubungan dengan kepuasan pasien. ${ }^{20}$

Usia tidak ditemukan berpengaruh terhadap kepuasan pasien. Skor kepuasan terhadap efisiensi pada kelompok usia 46-60 tahun lebih rendah dibandingkan kelompok usia di bawahnya. Temuan penelitian ini sejalan dengan suatu studi lainnya menemukan adanya tendensi penurunan kepuasan pada populasi pasien $>35$ tahun. Akan tetapi, studi ini tidak menemukan perbedaan secara statistik antar populasi $\leq 35$ tahun dan >35 tahun. ${ }^{17}$ Temuan survei ini juga didukung oleh Rahmqvist (2001) yang melaporkan pemodelan hubungan kepuasan pasien dengan usia dan faktor demografis lainnya. Studi menemukan adanya tren penurunan skor kepuasan yang bermakna seiring peningkatan usia pasien. ${ }^{21}$

Dalam survei ini, peneliti berhasil menggali kepuasan pasien di unit rawat jalan Rumah Sakit Medika Lestari berdasarkan berbagai aspek. Peneliti juga berhasil menggali hubungan kepuasan tersebut dengan faktor demografi, berupa usia dan jenis kelamin. Temuan ini diharapkan dapat menjadi bahan evaluasi pusat kesehatan dalam memberikan pelayanan terbaik kepada pasien. Terlepas dari hal-hal tersebut, terdapat beberapa kelemahan studi yang perlu peneliti garis bawahi. Kelemahan studi ini terutama diakibatkan oleh minimnya faktor yang peneliti ikutsertakan dalam analisis. Dalam studi ini, hanya terdapat 2 faktor (usia dan jenis kelamin) yang peneliti hubungkan dengan skor kepuasan. Terdapat berbagai faktor lainnya, seperti penyakit, tingkat pendidikan, ataupun frekuensi kunjungan yang dirasa dapat mempengaruhi kepuasan pasien. Oleh karena itu, diharapkan agar studi selanjutnya dapat melakukan penelitian dengan metode serupa, dengan menganalisis berbagai faktor perancu tambahan yang dapat mempengaruhi kepuasan pasien terhadap pelayanan unit rawat jalan suatu pusat kesehatan.

\section{KESIMPULAN}

Penerapan pendidikan dan pelatihan (diklat) online serta motivasi kerja terbukti secara signifikan berpengaruh terhadap kinerja pegawai penunjang medis di Rumah Sakit BaliMed Denpasar dengan nilai determinasi total sebesar 0,571 atau 57,1\%.

\section{UCAPAN TERIMAKASIH}

Peneliti mengucapkan terimakasih kepada Rumah Sakit BaliMed Denpasar yang telah memberikan kesempatan untuk melakukan penelitian ini, dan tidak lupa pula peneliti mengucapkan terimakasih kepada Universitas Bali Internasional yang memberikan banyak ilmu dan fasilitas kepada peneliti dalam menyelesaikan penelitian ini.

\section{DAFTAR PUSTAKA}

1. Butt AA, Kartha AB, Masoodi NA, et al. Hospital admission rates, length of stay, and in-hospital mortality for common acute care conditions in COVID-19 vs. pre-COVID-19 era. Public health 2020; 189: 6-11. 2020/10/31. DOI: 10.1016/j.puhe.2020.09.010.

2. Çıkrıkçı Işık G and Çevik Y. Impact of COVID-19 pandemic on visits of an urban emergency department. The American journal of emergency medicine 2021; 42: 78-82. 2021/01/26. DOI: 10.1016/j.ajem.2021.01.011.

3. Mafham MM, Spata E, Goldacre R, et al. COVID-19 pandemic and admission rates for and management of acute coronary syndromes in England. The Lancet 2020; 396: 381-389. DOI: https://doi.org/10.1016/S01406736(20)31356-8.

4. Mitchell RD, O'Reilly GM, Mitra B, et al. Impact of COVID-19 State of Emergency restrictions on presentations to two Victorian emergency departments. Emergency Medicine Australasia 2020; 32: 1027-1033. https://doi.org/10.1111/1742-6723.13606. 
DOI: $\quad$ https://doi.org/10.1111/17426723.13606.

5. Sanson-Fisher R, Bowman $\mathrm{J}$ and Armstrong S. Factors affecting nonadherence with antibiotics. Diagnostic Microbiology and Infectious Disease 1992; 15: 103-109. DOI: https://doi.org/10.1016/07328893(92)90136-H.

6. Bond WS and Hussar DA. Detection methods and strategies for improving medication compliance. American journal of hospital pharmacy 1991; 48: 1978-1988. 1991/09/01.

7. Svarstad BL, Shireman TI and Sweeney JK. Using Drug Claims Data to Assess the Relationship of Medication Adherence With Hospitalization and Costs. Psychiatric Services 2001; 52: 805-811. DOI: 10.1176/appi.ps.52.6.805.

8. Mosadeghrad AM. Factors Affecting Medical Service Quality. Iranian journal of public health 2014; 43: 210-220. 2014/02/01.

9. Jenkinson C, Burton JS, Cartwright J, et al. Patient attitudes to clinical trials: development of a questionnaire and results from asthma and cancer patients. Health Expectations 2005; 8: 244-252. https://doi.org/10.1111/j.1369-

7625.2005.00335.x.

DOI:

https://doi.org/10.1111/j.1369-

7625.2005.00335.x.

10. Merle V, Germain JM, Tavolacci MP, et al. Influence of infection control report cards on patients' choice of hospital: pilot survey. The Journal of hospital infection 2009; 71: 263-268. 2009/01/17. DOI: 10.1016/j.jhin.2008.11.025.

11. Pawlush GG. Health care marketing minicase. Journal of health care marketing 1981; 1: 49-52. 1982/03/07.

12. Roh CY, Lee KH and Fottler MD. Determinants of hospital choice of rural hospital patients: the impact of networks, service scopes, and market competition. Journal of medical systems 2008; 32: 343-353. 2008/07/16. DOI: 10.1007/s10916-008-9139-7.
13. Wisniewski $M$ and Wisniewski $H$. Measuring service quality in a hospital colposcopy clinic. International journal of health care quality assurance incorporating Leadership in health services 2005; 18: 217-228. 2005/06/25. DOI: $10.1108 / 09526860510594776$.

14. Luft HS, Garnick DW, Mark DH, et al. Does quality influence choice of hospital? Jama 1990; 263: 2899-2906. 1990/06/06.

15. Adams EK and Wright GE. Hospital Choice of Medicare Beneficiaries in a Rural Market: Why Not the Closest? The Journal of Rural Health 1991; 7: 134152. $\quad$ https://doi.org/10.1111/j.17480361.1991.tb00715.x. DOI: https://doi.org/10.1111/j.17480361.1991.tb00715.x.

16. Han JH, Sullivan N, Leas BF, et al. Cleaning Hospital Room Surfaces to Prevent Health Care-Associated Infections: A Technical Brief. Annals of internal medicine 2015; 163: 598-607. 2015/08/11. DOI: 10.7326/m15-1192.

17. Asamrew N, Endris AA and Tadesse M. Level of Patient Satisfaction with Inpatient Services and Its Determinants: A Study of a Specialized Hospital in Ethiopia. Journal of Environmental and Public Health 2020; 2020: 2473469. DOI: $10.1155 / 2020 / 2473469$.

18. Apisarnthanarak A, Weber DJ, Ratz D, et al. National Survey of Environmental Cleaning and Disinfection in Hospitals in Thailand. Infection Control \& Hospital Epidemiology 2017; 38: 1250-1253. 2017/08/30. DOI: 10.1017/ice.2017.171.

19. Ogaji D and Mezie-Okoye M. Waiting time and patient satisfaction: Survey of patients seeking care at the general outpatient clinic of the University of Port Harcourt Teaching Hospital. Port Harcourt Medical Journal 2017; 11: 148155.

20. Woods SE and Heidari Z. The influence of gender on patient satisfaction. The journal of gender-specific medicine: JGSM : the official journal of the 
Partnership for Women's Health at Columbia 2003; 6: 30-35. 2004/01/13.

21. Rahmqvist M. Patient satisfaction in relation to age, health status and other background factors: a model for comparisons of care units. International Journal for Quality in Health Care 2001; 13: 385-390. DOI: 10.1093/intqhe/13.5.385. 